\title{
Recent rates of carbon and nitrogen accumulation in peatlands of Isla Grande de Chiloé-Chile
}

\author{
Carolina A León ${ }^{1,2^{*}}$ and Gisela Oliván ${ }^{2}$
}

\begin{abstract}
Background: Peatlands play a key role in the global carbon cycle; these contain one third of the world's soil organic carbon, equivalent to more than half the amount of carbon in the atmosphere. Nevertheless, these ecosystems have been scarcely studied in southern South America. The main objective of this paper is to evaluate the recent accumulation rates of carbon $(C)$ and nitrogen $(N)$ in two kinds of oligotrofic peatlands in Isla Grande de Chiloé (Chile).

Results: Using peat $\mathrm{C}$ and $\mathrm{N}$ content, dry bulk density, and $\mathrm{Pb}-210$ dating, we determined the rates of $\mathrm{N}$ and $\mathrm{C}$ accumulation in profiles from five peatlands in the northern Chilean Patagonia. The recent rate of $\mathrm{C}$ accumulation (RERCA) ranges from 8.5 to $87.06 \mathrm{~g} \mathrm{C} \mathrm{m}^{-2}$ year $^{-1}$, and the recent rate of $\mathrm{N}$ accumulation (RERNA) ranges from 0.15 to $2.37 \mathrm{~g} \mathrm{~N} \mathrm{~m}^{-2} \mathrm{year}^{-1}$. The difference in RERCA and RERNA between glacial peatlands and anthropogenic peatlands was significant. One of the remarkable results is that accumulation of $\mathrm{N}$ and $\mathrm{C}$ are directly related.

Conclusions: This study contributes for a better understanding of the Patagonian peatlands of Chile. In addition, this research contributes by setting a basis for conducting further studies and for assessing the impacts of climate change on peatlands.
\end{abstract}

Keywords: Carbon accumulation; Nitrogen accumulation; Northern Patagonia; Oligotrophic peatlands; Pb-210

\section{Background}

A distinct characteristic of peatland ecosystems is a disequilibrium between primary production and decay; c. $2 \%$ to $16 \%$ of the biomass produced annually forms peat (Tolonen and Turunen 1996). In these habitats, the rate of carbon (C) sequestration in natural peatlands is larger than the total rate of $\mathrm{C}$ losses; therefore, their $\mathrm{C}$ stock continues to increase (Joosten and Couwenberg 2008). Peatlands have in the past 15,000 years withdrawn enormous amounts of carbon dioxide $\left(\mathrm{CO}_{2}\right)$ from the atmosphere and stored it in their peat deposits (Yu et al. 2003; Joosten and Couwenberg 2008). They play a key role in the global carbon cycle and are influenced by global climate change. These habitats account for $3 \%$ to $6 \%$ of the Earth's land surface and contain around 600 gigatonnes of C (Charman 2002; Charman et al. 2013; Clymo et al. 1998). This means that peat

\footnotetext{
* Correspondence: carolina.leon@ubo.cl

${ }^{1}$ Centro de Investigación en Recursos Naturales y Sustentabilidad,

Universidad Bernardo O'Higgins, Fábrica 1990, segundo piso, C. P. 8370846 Santiago, Chile

2Departamento de Biología Vegetal I, Facultad de Ciencias Biológicas, Universidad Complutense de Madrid, E-28040 Madrid, España
}

represents about one third of the total global soil $\mathrm{C}$ pool. It contains an equivalent of approximately two thirds of all $\mathrm{C}$ in the atmosphere and the same amount of $\mathrm{C}$ as all terrestrial biomass on earth (Joosten and Clarke 2002). Peatlands are the most space-effective carbon stocks of all terrestrial ecosystems. In the (sub)polar zone, peatlands contain on average at least 3.5 times per ha, in the boreal zone 7 times, and in the tropical zone 10 times more $\mathrm{C}$ per ha than all other ecosystems (Joosten and Couwenberg 2008).

Peatlands are unusual in greenhouse scenarios because they sequester the major greenhouse gas, $\mathrm{CO}_{2}$, from the atmosphere as peat. Nevertheless, on the other hand, they emit to it in large quantities both $\mathrm{CO}_{2}$ and the second most important greenhouse gas, $\mathrm{CH}_{4}$. Despite occupying a relatively small area of the earth's surface, $3 \%$ of the land and freshwater surface of the planet, these ecosystems process significant amounts of $\mathrm{CO}_{2}, \mathrm{CH}_{4}, \mathrm{H}_{2} \mathrm{~S}$, and $\mathrm{N}_{2} \mathrm{O}$ from the atmosphere. However, they can also become potential emitters of $\mathrm{CO}_{2}$ and $\mathrm{CH}_{4}$ if some of the factors involved in the development and dynamics of these ecosystems are destabilized. In this case, the potential impact of peatlands on the greenhouse effect and 
climate change would be decisive (Pontevedra Pombal et al. 2004). When the normally wet peat soils are in contact with the air, these soils begin to oxidize and decompose, releasing $\mathrm{CO}_{2}$ (Joosten and Couwenberg 2008). Some estimations indicate that peatland degradation contributes up to 0.8 gigatonne $C$ per year (Trumper et al. 2009). Peat accumulation shows a strong local and regional variation, and peat accumulation rates are dependent on climatic, hydrologic, and hydrochemical conditions (Joosten and Couwenberg 2008). In this sense, nitrogen $(\mathrm{N})$ deposition may also affect $\mathrm{C}$ accumulation through effects on plant productivity and rates of organic matter decomposition (Turunen et al. 2004; Limpens and Berendse 2003).

$\mathrm{C}$ accumulation in peat can be estimated by different methods and time scale. One of the methods is the recent rate of carbon accumulation (RERCA), and this refers to the fresh peat that is annually added to the peatland system (Joosten and Couwenberg 2008; Rydin and Jeglum 2006). This quantization is based on the column section between the surface and a given dated horizon in a surface core. Data of bulk density, C content, and chronologies are used (Tolonen and Turunen 1996).

In Europe, North America, and China there have been conducted numerous studies on recent carbon dynamics in peatland (Gorham 1991; Turunen et al. 2004; Tolonen and Turunen 1996; Pitkänen et al. 1999; Bao et al. 2010; Ali et al. 2008; Pontevedra Pombal et al. 2004). Nevertheless, similar studies are scarce in southern South America. In Chilean Patagonia, vast expanses of peatland can be found. A significant number of peatlands were formed by peat accumulation in open water after glacial retreat (Villagrán 1991; Villagrán 1988; Heusser 1984), referred to in this paper as glaciogenic peatland. Nevertheless, in northern Patagonia, the use of fire and clearcutting since the middle of the 19th century in places with low drainage have created areas of wetlands dominated by species of the genus Sphagnum L. (Díaz et al. 2008; Zegers et al. 2006). When Tepualia stipularis (Hook. \& Arn.) Griseb. forests on poorly drained soil are burned or cleared, waterlogged conditions impair the recolonization of forests and stimulate Sphagnum colonization (Díaz et al. 2007; Díaz and Silva 2012). These sites have been referred to as secondary or anthropogenic peatlands (Díaz et al. 2008).

The rate of $C$ sequestration in peatlands is a crucial element in understanding the global $\mathrm{C}$ cycle and has been estimated on different timescales to ascertain the role of peatlands in global warming in the context of rising atmospheric $\mathrm{CO}_{2}$ (Bao et al. 2010; Joosten and Clarke 2002). Added to this is that a better management of ecosystem carbon stocks and fluxes can substantially contribute to reducing atmospheric greenhouse gas concentrations (Joosten 2011).
Therefore, considering the above background, the aim of this paper is to describe some aspects of $\mathrm{C}$ and $\mathrm{N}$ accumulation through a comparative analysis of RERCA and the recent rate of nitrogen accumulation (RERNA) in anthropogenic and glaciogenic peatlands of Isla Grande de Chiloé (Chile) and also to establish the relationship between these rates.

\section{Methods}

\section{Study area}

The study area is situated on the Isla Grande de Chiloé, Región de Los Lagos in Chile ( $42^{\circ}$ to $43^{\circ} \mathrm{S}$ and $73^{\circ}$ to $\left.75^{\circ} \mathrm{W}\right)$. Chiloé's climate is wet temperate with a strong oceanic influence (di Castri and Hajek 1976). It has an annual mean temperature of $9.6^{\circ} \mathrm{C}$ (Carmona et al. 2010), and its annual rainfall ranges from 1,900 to $2,300 \mathrm{~mm}$ (CONAF 2009), reaching even between 5,000 to $6,000 \mathrm{~mm}$ in some areas (Pérez et al. 2003).

We selected five sites located in the northern and central parts of the island (Figure 1). Two kinds of Sphagnum peatlands were studied, which were defined according to their origin and their characteristic vegetation (Díaz et al. 2008). The first type, glaciogenic peatland, was originated after the last glaciation. The second type, anthropogenic peatland, corresponds to flooded areas colonized by Sphagnum moss after the burning or logging of forests in areas with poor drainage soils (Zegers et al. 2006; Díaz et al. 2008). The two study areas representing the glaciogenic peatland type were Los Caulles (CA) and Púlpito (PL), and the three study areas representing the anthropogenic peatland were Senda Darwin (SD), Río Chepu $(\mathrm{CH})$, and Teguel (TG).

\section{Core samplings}

The oligotrophic peatlands sampled were constituted of Sphagnum peat mainly of Sphagnum magellanicum Brid. In each locality, we took a short peat monolith $(30 \times 30 \times$ 45 to $50 \mathrm{~cm}$ ) with a sharpened metal sheet tin following the recommendations of De Vleeschouwer et al. (2010). The monoliths of peat were carefully extracted, wrapped in foil paper, and transported flat in rigid cases to be fractioned in subsequent hours. Approximately 4 to $5 \mathrm{~cm}$ from the outer layer of each monolith was removed to discard the material that was altered in the extraction and transportation. The monoliths were divided into intervals of 1 to $2 \mathrm{~cm}$ with a stainless steel saw.

Each segment was separated into two sub-samples: a small portion of $2 \mathrm{~cm}^{3}$ to calculate bulk density and the other one with the rest of the material. These samples were deposited in polyethylene bags and stored at $4^{\circ} \mathrm{C}$. The analyses were performed on some sections of the monoliths in non-continuous depths. 


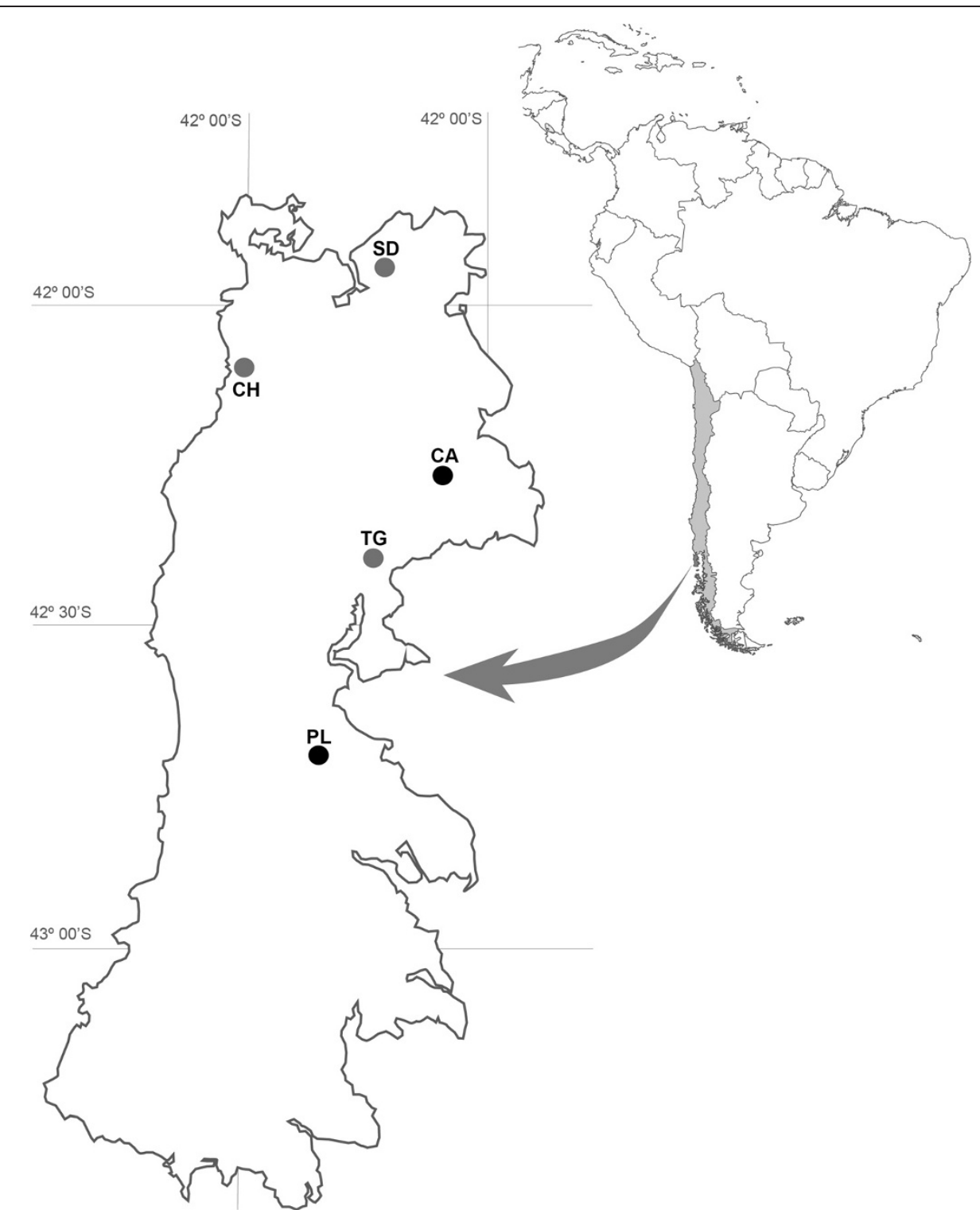

Figure 1 Study sites on Isla Grande de Chiloé. Glaciogenic peatlands: PL, Púlpito; CA, Caulles. Anthropogenic peatlands: SD, Senda Darwin; CH, Río Chepu; and TG, Teguel.

\section{Physicochemical analysis}

Water content and dry bulk density were obtained from weight loss by drying of a known volume of peat section at $105^{\circ} \mathrm{C}$ for $12 \mathrm{~h}$. The first one was calculated from the mass difference and the second one was calculated from stable weight and known volume (Martínez Cortizas et al. 2009; Bao et al. 2010; Sadzawka et al. 2006; Wang et al. 2004). Ash and organic matter content were determined by calcination at $550^{\circ} \mathrm{C}$ for $6 \mathrm{~h}$ in a muffle furnace (Martínez Cortizas et al. 2009; Bao et al. 2010; Sadzawka et al. 2006; Wang et al. 2004). Following the procedures of Tolonen and Turunen (1996), Clymo et al. (1998) and Bao et al. (2010), organic C content was calculated by multiplying the organic matter content by $0.50 \mathrm{~N}$ content was analyzed by complete combustion at $950^{\circ} \mathrm{C}$ using an elementar analyzer and following the protocol USDA (1996). C/N ratio was established as the ratio of total C and total $\mathrm{N}$. Calcination and $\mathrm{C} / \mathrm{N}$ ratio were performed at Centro de Espectrometría Atómica of Universidad Complutense de Madrid (Spain) and Laboratorio de Suelo of Instituto de Investigaciones Agropecuarias (Chile).

\section{Radiometric measurements and data analysis}

The activities of $\mathrm{Pb}-210$ were measured by gamma-ray spectrometry using hyper-pure germanium detectors in all areas sampled. However, in CAU and PUL, the concentration of $\mathrm{Pb}-210$ activity decreased to the limits of detection. In these localities, descendants of $\mathrm{Pb}-210$ and 
Po-210 were measured with alpha spectroscopy using passivated ion-implanted silicon (PIPS). These analyses were performed at Servicio de Radioisótopos of Universidad de Sevilla (Spain). The Constant Initial Concentration (CIC) model of Appleby and Oldfield (1978) and Sánchez-Cabeza and Ruiz-Fernández (2012) was applied to calculate the ages of peat layers.

We estimated RERCA and RERNA following the Bao et al. (2010) model which used g dry bulk density, age, and $\mathrm{C}$ or $\mathrm{N}$ contents, as appropriate.

STATISTICA 7.0 (StatSoft 2004) was used for statistics analysis. The normality of variables was evaluated by the Shapiro-Wilk and Kolmogorov-Smirnov tests. Pearson correlations between RERCA and RERNA were calculated. We used one-way ANOVA to compare $\mathrm{C}$ and $\mathrm{N}$ accumulation between glaciogenic and anthropogenic peatlands.

\section{Results}

\section{Water content and dry bulk density}

The water content of the peat samples ranged from $735 \%$ to $1,927 \%$, with outliers (206\% and $327 \%$ ) in the samples of SD. In SD and CA, a slight decrease of water content was observed in the deeper layers (Figure 2A). In the other localities, the water content shows slight variations along the depth.

The ranges of dry bulk density were 0.0100 to $0.065 \mathrm{~g} \mathrm{~cm}^{-3}$. In $\mathrm{SD}$, the dry bulk densities increased with depth. In contrast, we observed the opposite trend in $\mathrm{CH}$; the density decreases to deeper layers. In the other three sites, the dry bulk density shows no significant variations along the profiles (Figure 2B).

\section{Radioisotope chronology}

In $\mathrm{SD}, \mathrm{TG}$, and $\mathrm{CH}$ peatlands, the activities $\left(\mathrm{Bq} \mathrm{kg}{ }^{-1}\right)$ (Figure 2C) of $\mathrm{Pb}-210$ and $\mathrm{Ra}-226$ were well-defined.
However, in CA and PL from the third sample of each core, the activity decreased to the limits of detection of the technique. The activity was detected until 21 to $29-\mathrm{cm}$ depth in glaciogenic peatlands and 28 to $37 \mathrm{~cm}$ in anthropogenic peatlands. Table 1 shows the chronologies (years AD) inferred from the $\mathrm{Pb}-210$ using the $\mathrm{CIC}$ model.

\section{$\mathrm{C}, \mathrm{N}$ and $\mathrm{C} / \mathrm{N}$}

The calculated organic $\mathrm{C}$ values show differences among localities. The higher mean values \pm SD were observed in PL $(50.03 \% \pm 2.05 \%, n=3)$, CA $(47.3 \% \pm 3.74 \%, n=3)$, and $\mathrm{CH}(46.93 \% \pm 1 \%, n=3)$. The other two sites reported slightly lower mean values: TG $(44.8 \% \pm 1.8 \%, n=3)$ and $\mathrm{SD}(39.6 \% \pm 7.23 \%, n=4)$ (Figure 2D). The mean values of the $\mathrm{C}$ content were higher in glaciogenic peatlands.

The percentage of $\mathrm{N}$ varied between 0.74 and 2.28. The highest mean values \pm SD were reported in $\mathrm{CH}$ $(1.93 \% \pm 0.3 \%, n=3)$ and PL $(1.9 \% \pm 0.58 \%, n=3)$; secondly, CA $(1.26 \% \pm 0.34 \%, n=3)$, and then SD $(0.93 \% \pm$ $0.19 \%, n=4)$ and TG $(0.83 \% \pm 0.21 \%, n=3)$ (Figure $2 \mathrm{E}$ ).

The ranges of $\mathrm{C} / \mathrm{N}$ ratios were 21.59 and 67.93 . The highest mean values \pm SD were found in TG $(56.3 \pm 12.1, n=3)$ and SD $(43.7 \pm 10.2, n=3)$, then CA $(38.9 \pm 6.8, n=3), \mathrm{CH}$ $(24.5 \pm 3.1, n=3)$, and finally PL $(28.1 \pm 9.1, n=3)$. In $\mathrm{C} / \mathrm{N}$ ratio, we observed a slight trend to decrease at greater depths (Figure 2F).

\section{RERCA and RERNA}

The RERCA estimated are presented in Table 1. The location that showed the highest average rate $\pm \mathrm{SD}$ was TG $\left(58.18 \pm 25.20 \mathrm{~g} \mathrm{C} \mathrm{m}^{-2}\right.$ year $\left.^{-1}, n=3\right)$, secondly $\mathrm{CH}$ $\left(50.75 \pm 15.40 \mathrm{~g} \mathrm{C} \mathrm{m}^{-2}\right.$ year $\left.^{-1}, n=3\right)$, then SD (32.77 \pm $13.78 \mathrm{~g} \mathrm{C} \mathrm{m}^{-2}$ year $\left.^{-1}, n=4\right)$, CA $(15.45 \pm 7.2 \mathrm{~g} \mathrm{C}$ $\mathrm{m}^{-2}$ year $\left.^{-1}, n=3\right)$, and finally PL $(9.35 \pm 3.02 \mathrm{~g} \mathrm{C}$ $\mathrm{m}^{-2}$ year $\left.^{-1}, n=3\right)$. It is noted that anthropogenic

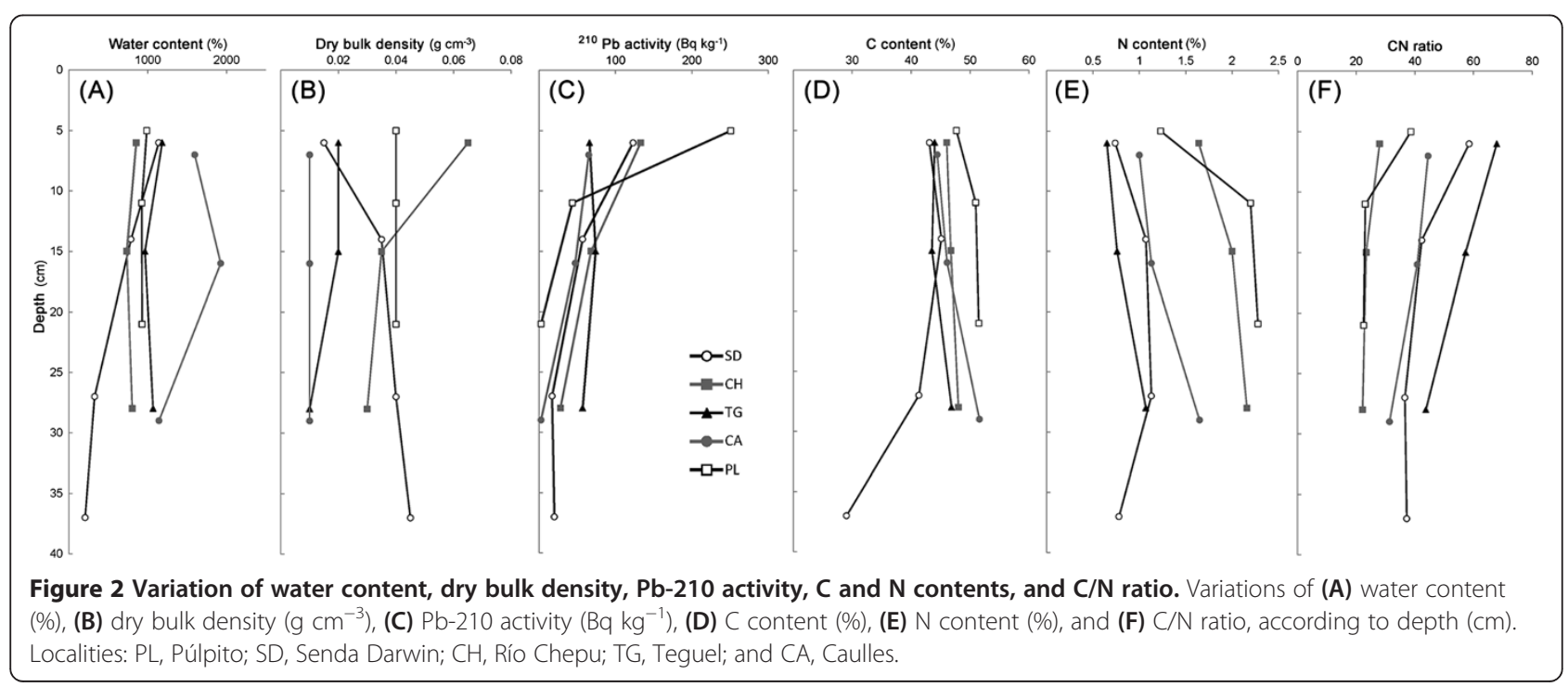




\begin{tabular}{|c|c|c|c|c|}
\hline Locality & $\begin{array}{l}\text { Depth } \\
\text { (cm) }\end{array}$ & $\begin{array}{l}\text { Chronology } \\
\text { (AD) }\end{array}$ & $\begin{array}{c}\text { RERCA } \\
\left(\mathrm{g} \mathrm{C} \mathrm{m}^{-2} \text { year }^{-1}\right) \\
\end{array}$ & $\begin{array}{c}\text { RERNA } \\
\left(\mathrm{g} \mathrm{N} \mathrm{m}^{-2} \text { year }^{-1}\right) \\
\end{array}$ \\
\hline \multirow[t]{4}{*}{ SD } & 6 & 1994 & 24.24 & 0.42 \\
\hline & 14 & 1944 & 33.50 & 0.79 \\
\hline & 27 & 1900 & 40.57 & 1.11 \\
\hline & 37 & 1925 & 56.88 & 1.53 \\
\hline \multirow[t]{3}{*}{$\mathrm{CH}$} & 6 & 1983 & 66.49 & 2.37 \\
\hline & 15 & 1961 & 50.08 & 2.14 \\
\hline & 28 & 1897 & 35.70 & 1.61 \\
\hline \multirow[t]{3}{*}{ TG } & 6 & 1997 & 40.62 & 0.60 \\
\hline & 15 & 1995 & 87.06 & 1.52 \\
\hline & 28 & 1982 & 46.85 & 1.07 \\
\hline \multirow[t]{3}{*}{$C A$} & 7 & 1989 & 14.81 & 0.33 \\
\hline & 16 & 1978 & 23.06 & 0.57 \\
\hline & 29 & 1834 & 8.50 & 0.27 \\
\hline \multirow[t]{3}{*}{$P L$} & 5 & 1853 & 5.88 & 0.15 \\
\hline & 11 & 1796 & 10.75 & 0.46 \\
\hline & 21 & 1632 & 11.42 & 0.51 \\
\hline
\end{tabular}

peatlands (TG, SD, and $\mathrm{CH}$ ) have higher RERCA than glaciogenic peatlands (PL and CA) in the last 100 years. Moreover, there is a highly significant difference between the two types of habitats as reported by one-way ANOVA $(\mathrm{F} 1,14=21.231, p=0.0004)$.

The Table 1 shows the estimated values of RERNA. The overall mean $\pm \mathrm{SD}$ was $0.97 \pm 0.68 \mathrm{~g} \mathrm{~N} \mathrm{~m}^{-2}$ year $^{-1}$ $(n=16)$. The location that presented the highest average rate $\pm \mathrm{SD}$ was $\mathrm{CH}\left(2.04 \pm 0.39 \mathrm{~g} \mathrm{~N} \mathrm{~m}^{-2}\right.$ year $\left.^{-1}, n=3\right)$, secondly TG $\left(1.06 \pm 0.46 \mathrm{~g} \mathrm{~N} \mathrm{~m}^{-2}\right.$ year $\left.^{-1}, n=3\right)$, and then SD $\left(0.77 \pm 0.47 \mathrm{~g} \mathrm{~N} \mathrm{~m}^{-2}\right.$ year $\left.^{-1}, n=4\right)$, CA $(0.39 \pm$ $0.15 \mathrm{~g} \mathrm{~N} \mathrm{~m}^{-2}$ year $\left.^{-1}, n=3\right)$, and PL $\left(0.37 \pm 0.19 \mathrm{~g} \mathrm{~N} \mathrm{~m}^{-2}\right.$ year $\left.^{-1}, n=3\right)$.

According to the results of one-way ANOVA, a highly significant difference between mean RERNA of anthropogenic and glaciogenic peatlands was observed (F1, $14=$ $12.09 ; p=0.0037$ ).

On the other hand, a strong, highly significant, and directly proportional relation $(r=0.81 ; n=16 ; p=0.0001)$ between RERNA and RERCA was observed. Figure 3 shows the Pearson's correlation.

\section{Discussion}

Globally, our results showed that there is a difference between the two types of peatlands studied and throughout the period studied in the content and storage of $\mathrm{C}$ and $\mathrm{N}$. Our study shows that glaciogenic peatlands present higher values of $\mathrm{C}$ content in relation to anthropogenic peatlands. This difference may be related to the trophic status of peatlands and the source of nutrients. Martínez

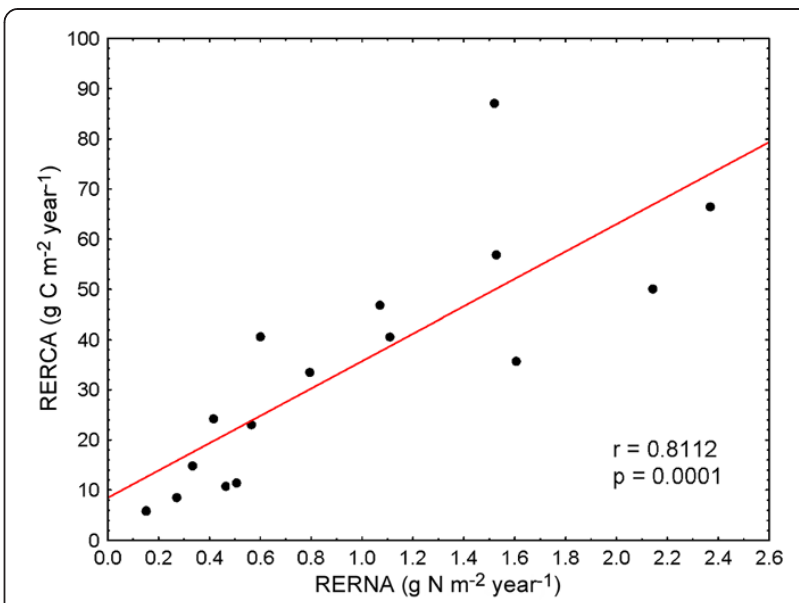

Figure 3 Relationship between RERNA and RERCA in peat profiles.

Cortizas et al. (2009) reported that ombrotrophic peatlands have much higher proportions of carbon than minerotrophic peatlands. These results concur with León (2012) who found that some anthropogenic peatlands as SD have transitional characteristics between minerotrophic and ombrotrophic, in contrast to $\mathrm{PL}$ or CA that are clearly ombrotrophic.

In general terms, we also note that N\% increased slightly in the first centimeters of the profiles. These results are consistent with other studies conducted in southern hemisphere islands where ombrotrophic peatlands with oceanic influence have nitrogen concentrations that increase progressively in the first centimeters deep, coinciding with the fluctuation zone above the water table (Damman 1988). This increase may be explained by the leaching of nitrogen from the well-drained higher layers (Damman 1988; Pontevedra Pombal et al. 2004). Kuhry and Vitt (1996) also show that nitrogen is lost from acrotelmo through denitrification, surface runoff, and erosion. Nevertheless, in bogs, most nitrogen is lost while being restrained in catotelmo.

According to our results, $\mathrm{C} / \mathrm{N}$ ratio values were similar to those reported for peatlands of northwestern Spain with an average of 34 (Pontevedra Pombal et al. 2004) and near the range reported for ombrotrophic peatlands in southern Sweden (Malmer et al. 1997). Nonetheless, our results are well below the highest values found in Tierra del Fuego where ratios reach values over 250 (Kleinebecker et al. 2008). The $\mathrm{C} / \mathrm{N}$ ratio has been considered as an important indicator of decomposition of organic matter (Martínez Cortizas et al. 2009). Highmean $\mathrm{C} / \mathrm{N}$ ratios found in ombrotrophic peatlands have been attributed to the low microbial activity in Sphagnum-rich peat due to the decomposition resistance of this material and the lack of easily assimilated energy, leading to the lack of biotic degradation of the organic matter (Pontevedra Pombal et al. 2004). 
On the other hand, mean values of RERNA fluctuated depending on the site ( 0.15 to $2.37 \mathrm{~g} \mathrm{~N} \mathrm{~m}^{-2}$ year $\left.^{-1}\right)$. These values are mostly within the ranges given for other geographic areas such as southern Sweden $\left(2 \mathrm{~g} \mathrm{~N} \mathrm{~m}^{-2}\right.$ year $\left.^{-1}\right)$ (Malmer and Holm 1984) or eastern Canada (1.4 to $3.2 \mathrm{~g} \mathrm{~N} \mathrm{~m}^{-2}$ year $^{-1}$ ) (Turunen et al. 2004). Nevertheless, in some sampled locations, significantly lower values were observed compared with those reported for the northern hemisphere. RERNA does not show a common pattern throughout cores: in two sites, RERNA increases with depth; in one site decreases; and in the other two sites increases and decreases. Therefore, to understand the variation of nitrogen, it is necessary to consider specific covariables for each study area, such as precipitation, temperature, and nitrogen atmospheric deposition, among others (Turunen et al. 2004).

We also noted that anthropogenic peatland sites (TG, $\mathrm{SD}$, and $\mathrm{CH}$ ) have higher accumulation rates of carbon during the last 100 years than glaciogenic peatland sites (PL and CA), which may indicate that anthropogenic peatlands, being novel ecosystems, are more active. Several studies in boreal Sphagnum peatlands shown that carbon accumulation rates are significantly higher in recent peat deposits, and the average carbon accumulation decreases over time by the slow decomposition that takes place in deeper and anoxic layers of peat (Tolonen and Turunen 1996; Turunen et al. 2004; Gorham 1991; Clymo et al. 1998). Nevertheless, it is important to note that the average of carbon percentage is higher in glacial peatlands, which would store carbon more efficiently.

The results of the five profiles do not show a general trend of increase or decrease in the carbon accumulation rates in relation to depth. Specifically, the observed trend changes depending on the site. The variation between the profiles could be attributed to intrinsic characteristics of the sites such as geological or climatic conditions, as well as variations of the sampling site nanotopography. Turunen et al. (2004) found a substantial variation in carbon accumulation between and within peatlands, depending if the profile had been extracted in mounds or depressions. This pattern was also reported by Økland and Ohlson (1998).

In an exploratory way, climatic variables with RERCA and RERNA were correlated. Precipitation and mean annual temperature data were obtained from the two closest meteorological stations to the study sites: Ancud (north side of the island) and Puerto Montt (63 km north of the island). Nonetheless, no significant correlation was observed. In our opinion, these results could be attributed to the lack of quality in the used data rather than to a nonsignificant correlation between accumulation and climatic conditions, as there is a lack of historical climate information on the island.
Furthermore, our results also show a strong and highly significant correlation between carbon and nitrogen accumulation rates, which is consistent with the patterns found by Moore et al. (2005). This important relationship can be understood considering that nitrogen is a limiting nutrient in these ecosystems (Malmer 1990) and that it is involved in productivity and rates of peat decomposition.

\section{Conclusions}

In this study, we have presented the recent accumulation rates of carbon and nitrogen from a type of ecosystem that has great influence on the global carbon balance. On the basis of these results, we noted the need for more detailed and accurate studies of chronologies in order to compare values of carbon accumulation with obtained data for other geographic areas. Similarly, there are important questions related to the influence of the deposition of atmospheric nitrogen on carbon accumulation and biomass production of Sphagnum and associated vascular plants. On the other hand, it is also highly relevant to continue the study of carbon dynamics in the Patagonian peatlands due to the high threat faced by the exploitation of peat and live moss and for the relevance these ecosystems have on climate change. Finally, this research also contributes by setting a basis for conducting further studies and for assessing the impacts of climate change on peatlands.

\section{Competing interests}

The authors declare that they have no competing interests.

\section{Authors' contributions}

CAL designed the study, performed research, analyzed data and wrote the paper. GOM designed the study, contributed to field work and manuscript development. Both authors read and approved the final manuscript.

\section{Acknowledgements}

This research was supported by grants AECID A/025081/2009, Cooperación a Desarrollo UCM 4138114, and AECID A/030011/2011. We are very grateful to Dr. (c) Alfonso Benítez-Mora for his assistance in the field. We wish to thank the Fundación Senda Darwin, Aserradero A.R.P., Chepu adventures, I. Municipalidad de Dalcahue, and CONAF Chiloé for their logistic support during field work and Prof. Gracielle Pereira Rocha at the Academic Writing Center from the U.S. Embassy in Chile for her assistance with English language editing.

C. A. León acknowledges the support of the doctoral fellowship provided by CONICYT-Gobierno de Chile.

This is a contribution to the Research Program of LTSER-Chile network at Senda Darwin Biological Station, Chiloé, Chile.

Received: 3 March 2014 Accepted: 22 October 2014

Published online: 05 November 2014

\section{References}

Ali AA, Ghaleb B, Garneau M, Asnong H, Loisel J (2008) Recent peat accumulation rates in minerotrophic peatlands of the Bay James region, Eastern Canada, inferred by $210 \mathrm{~Pb}$ and $137 \mathrm{Cs}$ radiometric techniques. Appl Radiat Isotopes 66(10):1350-1358

Appleby PG, Oldfield F (1978) The calculation of lead-210 dates assuming a constant rate of supply of unsupported $210 \mathrm{~Pb}$ to the sediment. CATENA $5(1): 1-8$

Bao K, Yu X, Jia L, Wang G (2010) Recent carbon accumulation in Changbai Mountain Peatlands, Northeast China. Mt Res Dev 30(1):33-41 
Carmona MR, Aravena JC, Bustamante-Sanchez MA, Celis-Diez JL, Charrier A, Díaz IA, Díaz-Forestier J, Díaz MF, Gaxiola A, Gutiérrez AG, Hernandez-Pellicer C, Ippi S, Jaña-Prado R, Jara-Arancio P, Jimenez J, Manuschevich D, Necochea P, Nuñez-Avila M, Papic C, Pérez C, Pérez F, Reid S, Rojas L, Salgado B, SmithRamírez C, Troncoso A, Vásquez RA, Willson MF, Rozzi R, Armesto JJ (2010) Estación Biológica Senda Darwin: investigación ecológica de largo plazo en la interfase ciencia-sociedad. Rev Chil Hist Nat 83:113-142

Charman D (2002) Peatlands and Environmental Change. J. Wiley \& Sons, London \& New York

Charman DJ, Beilman DW, Blaauw M, Booth RK, Brewer S, Chambers FM, Christen JA, Gallego-Sala A, Harrison SP, Hughes PDM, Jackson ST, Korhola A, Mauquoy D, Mitchell FJG, Prentice IC, van der Linden M, De Vleeschouwer F, Yu ZC, Alm J, Bauer IE, Corish YMC, Garneau M, Hohl V, Huang Y, Karofeld E, Le Roux G, Loisel J, Moschen R, Nichols JE, Nieminen TM et al (2013) Climate-related changes in peatland carbon accumulation during the last millennium. Biogeosciences 10(2):929-944

Clymo RS, Turunen J, Tolonen K (1998) Carbon accumulation in peatland. Oikos 81(2):368-388

CONAF (2009) Plan de Acción Provincial Chiloé - Plan de Gestión Territorial. Oficina Provincial Chiloé - Corporación Nacional Forestal, Castro

Damman AWH (1988) Regulation of nitrogen removal and retention in Sphagnum bogs and other peatlands. Oikos 51(3):291-305

De Vleeschouwer F, Chambers FM, Swindles GT (2010) Coring and sub-sampling of peatlands for palaeoenvironmental research. Mires Peat 7:1-10

di Castri F, Hajek ER (1976) Bioclimatología de Chile. Editorial Universidad Católica de Chile, Santiago, Chile

Díaz MF, Silva W (2012) Improving harvesting techniques to ensure Sphagnum regeneration in Chilean peatlands. Chil J Agr Res 72(2):296-300

Díaz MF, Bigelow S, Armesto JJ (2007) Alteration of the hydrologic cycle due to forest clearing and its consequences for rainforest succession. Forest Ecol Manag 244(1-3):32-40

Díaz MF, Larraín J, Zegers G, Tapia C (2008) Caracterización florística e hidrológica de turberas de la Isla Grande de Chiloé, Chile. Rev Chil Hist Nat 81:445-468

Gorham E (1991) Northern peatlands: role in the carbon cycle and probable responses to climatic warming. Ecol Appl 1(2):182-195

Heusser CJ (1984) Late-glacial-holocene climate of the Lake District of Chile. Quatern Res 22:77-90

Joosten H, Clarke D (2002) Wise use of mires and peatlands. Background and principles including a framework for decision-making. International Mire Conservation Group \& International Peat Society, Saarijarvi, Finland

Joosten H, Couwenberg J (2008) Peatlands and carbon. In: Parish F, Sirin A, Charman D et al (eds) Assessment on Peatlands, Biodiversity and Climate Change: Main Report Global Environment Centre. Kuala Lumpur and Wetlands International, Wageningen

Joosten H (2011) Selling peatland rewetting on the compliance carbon market. In: Tanneberger F, Wichtmann W (eds) Carbon credits from peatland rewetting: climate, biodiversity, land use. Schweizerbart science, Stuttgart, Germany

Kleinebecker T, Holzel N, Andreas V (2008) South Patagonian ombrotrophic bog vegetation reflects biogeochemical gradients at the landscape level. J Veg Sci 19(2):151-160

Kuhry P, Vitt DH (1996) Fossil carbon/nitrogen ratios as a measure of peat decomposition. Ecology 77(1):271-275

León CA (2012) Caracterización florística y ecológica de turberas esfagnosas de la isla Grande de Chiloé-Chile: una herramienta para la conservación y el desarrollo sostenible. Tesis Doctoral, Universidad Complutense de Madrid, Madrid

Limpens J, Berendse F (2003) How litter quality affects mass loss and N loss from decomposing Sphagnum. Oikos 103(3):537-547

Malmer N (1990) Constant or increasing nitrogen concentrations in Sphagnum mosses on mires in southern Sweden during the last few decades. Aquilo Ser Bot 28:57-65

Malmer N, Holm E (1984) Variation in the C/N-quotient of peat in relation to decomposition rate and age determination with 210Pb. Oikos 43:171-182

Malmer N, Svensson G, Wallén B (1997) Mass balance and nitrogen accumulation in hummocks on a South Swedish bog during the late Holocene. Ecography 20(6):535-549

Martínez Cortizas A, Pontevedra Pombal X, Nóvoa Muñoz JC, Rodríguez Fernández R, López-Sáez JA (2009) Turberas ácidas de esfagnos. In: Martínez Cortizas A (ed) Bases ecológicas preliminares para la conservación de los tipos de hábitat de interés comunitario en España. Ministerio de Medio Ambiente, y Medio Rural y Marino, Madrid
Moore T, Blodau C, Turunen J, Roulet N, Richard PJH (2005) Patterns of nitrogen and sulfur accumulation and retention in ombrotrophic bogs, eastern Canada. Glob Chang Biol 11(2):356-367

Økland RH, Ohlson M (1998) Age-depth relationships in Scandinavian surface peat: a quantitative analysis. Oikos 82(1):29-36

Pérez CA, Armesto JJ, Torrealba C, Carmona MR (2003) Litterfall dynamics and nitrogen use efficiency in two evergreen temperate rainforests of southern Chile. Austral Ecol 28(6):591-600

Pitkänen A, Turunen J, Tolonen K (1999) The role of fire in the carbon dynamics of a mire, eastern Finland. Holocene 9(4):453-462

Pontevedra Pombal X, Martínez Cortizas A, Buurman P (2004) Las turberas de montaña de Galicia como sumideros de carbono. Edafología 11(3):295-307

Rydin H, Jeglum JK (2006) The Biology of Peatlands. Biology of Habitats. Oxford University Press,

Sadzawka A, Carrasco MA, Grez R, Mora ML, Flores P, Neaman A (2006) Métodos de análisis de suelos recomendados para los suelos de Chile, Serie Actas INIA $N^{\circ}$ 34. Instituto de Investigaciones Agropecuarias, Santiago, Chile

Sánchez-Cabeza JA, Ruiz-Fernández AC (2012) 210Pb sediment radiochronology: an integrated formulation and classification of dating models. Geochim Cosmochim Acta 82:183-200

StatSoft (2004) STATISTICA for Windows, user's guide (version 7.0) StatSoft Inc, Tulsa

Tolonen K, Turunen J (1996) Accumulation rates of carbon in mires in Finland and implications for climate change. Holocene 6(2):171-178

Trumper K, Bertzky M, Dickson B, van der Heijden G, Jenkins M, Manning P (2009) The Natural Fix? The Role of Ecosystems in Climate Mitigation. A UNEP Rapid Response Assessment. United Nations Environment Programme, UNEPWCMC, Cambridge, UK

Turunen J, Roulet NT, Moore TR, Richard PJH (2004) Nitrogen deposition and increased carbon accumulation in ombrotrophic peatlands in eastern Canada. Global Biogeochem Cycles 18(GB3002):12

USDA (1996) Soil survey laboratory methods manual. Soil Survey Investigations Report N 42. Version 3.0. United States Department of Agriculture Washington, District of Columbia, USA

Villagrán C (1988) Late quaternary vegetation of Southern Isla Grande de Chiloé, Chile. Quatern Res 30:304-314

Villagrán C (1991) Historia de los bosques templados del sur de Chile durante el Tardiglacial y Postglacial. Rev Chil Hist Nat 64:447-460

Wang GP, Liu JS, Tang J (2004) The long-term nutrient accumulation with respect to anthropogenic impacts in the sediments from two freshwater marshes (Xianghai Wetlands, Northeast China). Water Res 38(20):4462-4474

Yu ZC, Vitt DH, Campbell ID, Apps MJ (2003) Understanding Holocene peat accumulation pattern of continental fens in western Canada. Can J Bot 81 (3):267-282

Zegers G, Larraín J, Díaz MF, Armesto JJ (2006) Impacto ecológico y social de la explotación de pomponales y turberas de Sphagnum en la Isla Grande de Chiloé. A\&D 22:28-34

doi:10.1186/s40693-014-0026-y

Cite this article as: León and Oliván: Recent rates of carbon and nitrogen accumulation in peatlands of Isla Grande de Chiloé-Chile. Revista Chilena de Historia Natural 2014 87:26.

\section{Submit your manuscript to a SpringerOpen ${ }^{\circ}$ journal and benefit from:}

- Convenient online submission

$\checkmark$ Rigorous peer review

- Immediate publication on acceptance

- Open access: articles freely available online

- High visibility within the field

- Retaining the copyright to your article

Submit your next manuscript at $\gg$ springeropen.com 